Francesco Dall'Aglio (Sofia)

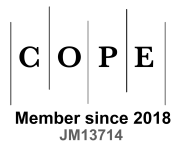

(iD) https://orcid.org/0000-0003-3318-7011

\title{
INNOCENT III AND SOUTH-EASTERN EUROPE: Orthodox, Heterodox, or Heretics?*
}

\begin{abstract}
7 he pontificate of Innocent III (1198-1215) was one of the most significant 1 in the history of the medieval Roman Church ${ }^{1}$. Among the many achievements of Innocent, we may certainly list the convocation of the fourth Lateran council, the organization of two crusades, the careful handling of the imperial succession in the West, a redefinition and modernization of the pontifical administrative structure, a renewed missionary activity in the pagan lands of North-eastern Europe and, concerning more specifically the theme of the present meeting, great efforts towards the unification of the Western and Eastern Church, especially after the Fourth Crusade and the establishment of a Latin empire in Constantinople, and the containment or, if possible, the eradication of any discordant voice within Christianity, either clearly heretical or simply heterodox. South-eastern Europe was one of the areas in which he directed his activities with greater energy. He was very proud of the results he obtained: in a letter sent on 21 January 1205 and addressed to the Latin clergy of Constantinople, he stated that
\end{abstract}

wherever I have cast my nets, according to the word of God, I have gathered, together with my brothers, a great abundance of fish, either in Livonia, converting the pagans [...] either in Bulgaria and Vlachia, bringing back to unity those who had strayed ${ }^{2}$.

\footnotetext{
*I wish here to thank the organisers of the International Conference "Orthodoxy-Heterodoxy. Slavic space facing the divisions of Christianity from the Middle Ages to today", held in Naples on 22-23 November 2018, were the first draft of this paper was originally delivered, and the anonymous reviewers whose suggestions help me improve the final version of the text.

${ }^{1}$ On Innocent III see especially J.C. Moore, Pope Innocent III (1160/61-1216). To Root up and to Plant, Leiden 2003; Innocenzo III. Urbs et Orbis. Atti del Congresso Internazionale (Roma, 9-15 settembre 1998), vol. II, ed. A. SOMMERLECHNER, Rome 2003.

${ }^{2}$ sed ubi ego in verbo Dei laxavi rete, conclusimus ego et fratres mei piscium multitudinem copiosam, sive in Liuonia convertendo paganos [...] sive in Bulgaria et Blachia reducendo divisos ad unitatem: Die Register Innocenz' III, 7. Pontifikatsjahr, 1204/1205: Texte und Indices, ed. O. Hageneder et al., Vienna 1997, p. 355.
} 
While the traditional view of Innocent had usually been that of a pontiff exclusively preoccupied with establishing a tight control on every aspect of the Church, including the promotion and the management of the crusades, more recent and balanced studies have pointed out that, while indeed a careful and scrupulous organiser, and a cunning politician firmly persuaded that the bishop of Rome had indeed the right to be considered the leading figure of the universal Church, his position on many issues, especially on crusade organization and the fight against heresy, was quite pragmatic and, when necessary, subject to evolution and change ${ }^{3}$. This is particularly evident when analysing his involvement with the politics and the religious organization of South-eastern Europe; such an analysis may provide an important contribute towards a better understanding of the general features of his pontificate, especially because his interest for the region, and the activity of his legates therein, are usually neglected in the scholarly literature not originating in Eastern Europe.

In the last quarter of the $12^{\text {th }}$ century the political landscape of the region, previously more or less tightly controlled by the Byzantine empire, had changed radically. Both Serbia and Bulgaria had been able to secure their independence, profiting from a series of favourable circumstances. Both states were in need of international legitimization, something that, for obvious reasons, would not come from Constantinople which considered their territories a part of its domains, and their leaders as rebels. At the same time Innocent III, thoroughly involved in the organization of the Fourth Crusade and engaged in an acrimonious polemic with the patriarch of Constantinople regarding the union of the western and eastern Churches ${ }^{4}$, was looking for every available opportunity to persuade, or compel, the Byzantine empire to cooperate. Attracting within the Roman influence those states, recently formed and still looking for some external authority to support them, would allow the pontiff to increase the diplomatic pressure on Constantinople, further isolating it within a constellation of hostile polities, and to intervene

\footnotetext{
${ }^{3} \mathrm{~J}$. BIRD, Innocent III, Peter the Chanter's Circle, and the Crusade Indulgence: Theory, Implementation, and Aftermath, [in:] Innocenzo III. Urbs et Orbis..., vol. I, ed. A. SOMMERLECHNER, p. 503-524 (especially p. 503-504: Innocent's initiatives in these areas were not necessarily attempts to monopolize the control of the crusade or use it as an instrument of papal 'plenitudo potestatis' against local churches and secular powers [...] Innocent's policy [...] was not a prescient, comprehensive and inflexible program, but evolved during his pontificate as part of a dialogue with his former masters and fellow students at Paris, the laity, the episcopate, and the military leaders of the crusade); R. KAY, The Albigensian Twentieth of 1221-3: an Early Chapter in the History of Papal Taxation, JMH 6, 1980, p. 307-311; J.M. Powell, Anatomy of a Crusade, 1213-1221, Philadelphia 1986, p. 89-106.

${ }^{4}$ See A. Papadakis, A.M. Talbot, John X Camaterus Confronts Innocent III: an Unpublished Correspondence, Bsl 33, 1972, p. 26-41; J. SPITERIS, La critica bizantina del primato romano nel secolo XII, Rome 1979, p. 248-299, 324-331; G. FedAlto, La Chiesa latina in Oriente, vol. I, ${ }^{2}$ Verona 1981, p. 283-285; J.M. PoweLL, Innocent III and Alexios III: a Crusade Plan that Failed, [in:] The Experience of Crusading, vol. I, ed. M. BulL, N. Housley, Cambridge 2003, p. 96-102.
} 
in the ecclesiastic organization of a region in which, with the exclusion of the Adriatic littoral, Rome traditionally did not enjoy a particularly strong presence.

Consequentially, Innocent III showed a great interest for three areas in particular: Dioclea, Bosnia and Bulgaria. The first two regions were under the jurisdiction of the crown of Hungary, which will be excluded from this survey because of its generally orthodox position and its obedience to Rome. The empire of Constantinople will be excluded as well, since the relations between the pope and the patriarch, and the confusion brought forth by the Latin conquest of Constantinople would necessitate a treatment that would go well beyond the chronological limits set for this paper.

It is possible to follow the moves of Innocent and of his interlocutors thanks to the large amount of correspondence preserved in the pontifical registers. The collection is incomplete and not homogeneous, and it records only about one fifth of Innocent's correspondence, often in abridged form: this limit notwithstanding, it is an extremely useful source for the study of the relations between Rome and South-eastern Europe during his pontificate. In the pontifical letters, not only in those addressed to the geographic area under scrutiny, religious and political issues are intertwined: however paradoxical it may seem, the political undertones appear to be prevalent. After all, besides being the primate of the Roman Church, Innocent was also a head of state and his concerns were not only of a religious nature, especially in an area yet to be brought under the influence of Rome. His legates, who received the mandate to uproot and tear down, to build and to plant, according to one of the biblical quotation that Innocent was most fond of ${ }^{5}$, knew well that their jurisdiction was not exclusively limited to religious issues.

The first documented contact between Innocent III and South-eastern Europe dates back to January 1199. Vukan, the firstborn son of the Grand Župan of Serbia Stefan Nemanja, was engaged in a conflict with his brother, also called Stefan, and asked for the assistance of the Hungarian king Imre. Maybe following the advice of the king, or maybe of his own decision, Vukan sent a letter to Rome, asking for the protection of the pope and for a legate to be sent in his lands. The registers record the obliging answer of Innocent ${ }^{6}$, who saw the possibility to gain a useful ally on the eastern shores of the Adriatic See and to expand the influence of Rome in the region. The pope sent to Vukan's court the chaplain John of Casamari ${ }^{7}$, in what would be the first of a long series of missions that will bring him, in the following years, to Constantinople, Bosnia, Hungary, and Bulgaria.

\footnotetext{
${ }^{5}$ Jer. 1, 10 (Ecce constitui te hodie super gentes et super regna, ut evellas et destruas et disperdas et dissipes et aedifices et plantes).

${ }^{6}$ Die Register Innocenz' III, 1. Pontifikatsjahr, 1198/1199: Texte, ed. O. Hageneder, A. Haidachert, Graz-Köln 1964, p. 759-760.

${ }^{7}$ Die Register Innocenz' III, 1. Pontifikatsjahr, p. 758. On Casamari and his activity see Giovanni da Casamari in Dalmazia e Bosnia, ed. N. Veselic, Rome 2019; R. Elze, Die päpstliche Kapelle im 12. und 13. Jahrhundert, ZSSR.KA 36, 1, 1950, p. 145-204 (here, p. 181-183); N. KAMP, Kirche und Mon-
} 
Once landed in Antivari, John was able to examine throughly the region and took care of the situation of the local clergy, which in many ways did not appear to be, and was in fact not, in accordance with the ecclesiastical dictates. It is not possible to speak of a heterodox attitude of the Dioclean Church, and it does not seem that in the region had existed any manifest heresy, which would have been reported to the pope and would have elicited a very different response from John. However, the discipline and the customs of the local clergy were very lax, something that can be understandable in an isolated province which had been subjected in the past to the influx of both Rome and Constantinople. Whit his usual energy, John of Casamari worked hard and, in the end, successfully: the local clergy gathered in a council and drew up a document in which it recognized the errors pointed out by John, and promised to correct them ${ }^{8}$.

Besides some procedural matters regarding the division of tithes, the correct procedure for the ordination of priests and the punishment to be imposed on those who violated the seal of confession or were guilty of simony, things therefore not necessarily connected to heterodox beliefs of practices, what according to John had to be reformed with the maximum care and urgency was the marriage of priests, which appeared quite widespread and was probably a consequence of the influx of eastern Christianity. The solution proposed by the legate, and forcefully accepted by the local clergy, was necessarily severe: the prelates who had contracted matrimony before receiving the ecclesiastical ordination were to leave the Church, unless their wives swore an oath of chastity in the presence of the local bishop. If, on the other hand, the matter was more simply that of a 'more uxorio' concubinage, without a proper marriage, the guilty prelate would be divested unless he did a suitable penance for his misdeeds. Finally, the prescribed shaving and tonsure was not observed by the ecclesiastics, and there seemed to be some kind of laxity when dealing with the thorny issue of marriage between blood relatives: again, rather than a proof of heterodoxy, it would be more appropriate to consider those issues as the consequence of a widespread ignorance of the canons, arising from the relative isolation of the ecclesiastical community and not from a conscious decision to deviate from the norms.

Much more interesting is the mention, contained in a letter sent by Vukan to Innocent, of a proper heresy that, according to the Serbian ruler, was spreading throughout Bosnia'. In an alarmed tone, Vukan reported that at least ten thousand people were openly practicing it, and that among them there were Kulin,

archie im staufischen Königreich Sizilien. Prosopographische Grundlegung: Bistümer und Bischöfe des Königreichs 1194-1266, vol. I, Munich 1973, p. 18-20; W. MALECZEK, Papst und Kardinalkolleg von 1191 bis 1216, Vienna 1984, p. 340.

${ }^{8}$ Die Register Innocenz' III, 2. Pontifikatsjahr, 1199/1200: Texte, ed. O. Hageneder et al., RomeVienna 1979, p. 326-330. The letter was sent to Innocent III by archbishop John of Antivari, and contains the charter signed by the local clergy in the presence of the papal legates (p. 327-330).

${ }^{9}$ Die Register Innocenz' III, 2. Pontifikatsjahr, p. 323-325. 
the ban of the region, his wife and his sister, the widow of the deceased count of Chelm, in Herzegovina. Since the Bosnian land was subjected to the authority of the king of Hungary, he had ordered the Bosnian clergy to send some representatives to Rome and ask for the judgement of the pope: but they had presented him false letters in which it was written that the pontiff had approved their rule ${ }^{10}$. It is unclear what Imre did at this point, but Vukan suggested to Innocent to write and exhort him to eradicate them from his kingdom. Preoccupied, Innocent did so on 11 October $1200^{11}$.

The character of this supposed heresy (more correctly, non-conformity), often and superficially associated to bogomilism, is one of the most important problems of the history of medieval Bosnia ${ }^{12}$. The term 'bogomilism' is never mentioned, either by the pope or by his correspondents; on the other hand, the situation in Bosnia was clearly labelled heresis, and in some instances even catharorum her$e s i s^{13}$, a sign that the pope and his legates considered it equivalent to the heresies spreading in the West at the same time. It is hard to ascertain whether this was a simplification, an exaggeration, a misunderstanding, or the truth. In the letter written to Imre, the sanctions that Kulin, under his supervision, should implement against the Bosnians were the same listed, on 25 April 1199, in the famous 'Vergentis in senium' decretal addressed to the clergy, the consuls and the people of Viterbo ${ }^{14}$ : after two admonitions, those persisting in their heretic beliefs and those who protected or sheltered them should be banned from holding public offices and expelled from city councils; they could not participate in any election,

${ }^{10}$ Illi autem simulatis litteris redierunt, dicentes a vobis concessam sibi legem: Die Register Innocenz' III, 2. Pontifikatsjahr, p. 325.

${ }^{11}$ Vetera monumenta slavorum meridionalium historiam illustrantia, vol. I, ed. A. TheINer, Rome 1836, p. 12-13; Acta Innocentii PP. III (1198-1216), ed. T. HalušČYNSKYJ, Vatican City 1944 [= PCR CICO.F, 3.2], p. 209; Regesta pontificum romanorum, vol. I, ed. A. Роттнаst, Graz 1957, n. 1142.

${ }^{12}$ For a survey of the most recent historiography about the Bosnian 'heresy', see D. DAutović, Crkva Bosanska: moderni historiografski tokovi, rasprave i kontroverze (2005-2015), HTra 15, 2015, p. 127-160. See also Z. ŠTimaC, Die bosnische Kirche. Versuch eines religionswissenschaftlichen Zugangs, Frankfurt 2004; Fenomen "krstjani" u srednjovjekovnoj Bosni i Humu, ed. F. ŠAnjeK, Sarajevo-Zagreb 2005; G. Barabás, Heretics, Pirates, and Legates. The Bosnian Heresy, the Hungarian Kingdom, and the Popes in the Early $13^{\text {th }}$ Century, SNPP.SM 9, 2017, p. 35-58; J.V.A. Fine, JR., The Bosnian Church. A New Interpretation, New York 1975, p. 121-134. For the traditional interpretation of the Bosnian Church as influenced by bogomilism, see J. Hamilton, B. Hamilton, Christian Dualist Heresies in the Byzantine World c. 650-c. 1450, Manchester 1998, p. 47-48. On the general history of Bosnia during this period see E. Filipović, Bosansko kraljevstvo. Historija srednjovjekovne bosanske države, Sarajevo 2016, p. 49-65.

${ }^{13}$ See, for instance, Die Register Innocenz' III, 5. Pontifikatsjahr, 1202/1203: Texte, ed. O. Hageneder et al., Vienna 1993, p. 218: dampnata Catharorum heresi.

${ }^{14}$ Die Register Innocenz' III, 2. Pontifikatsjahr, p. 3-5. The measures to be taken against the local heretics are listed on p. 4, and are integrally reproduced in the letter written to Imre. On this decretal, see O. Hageneder, Studien zur Dekretale "Vergentis" (X. V, 7, 10): Ein Beitrag zur Häretikergesetzgebung Innocenz' III, ZSSR.KA 49, 1963, p. 138-173. 
give testimony in a process, make a will or receive any inheritance. If they were lawyers or notaries, all the documents redacted by them were to be considered null and void. If those sanctions would not convince them to retract their beliefs, they would be anathemised, all their belongings would be impounded, and they would be exiled. Should Kulin neglect or fail to enforce those measures against the heretics, Imre had the right to confiscate his properties and his land: the same authorization would be given in 1208 to Philip Augustus of France, regarding the lands of Raymond VI of Tolouse, in a more explicit, structured, and rhetorically elaborate way ${ }^{15}$. The allegations about Kulin's own heterodoxy were more detailed and specific than the rumours reported by Vukan: Innocent had been informed that many heretics, exiled from Split and Trogir, had found shelter in Bosnia where Kulin offered to their iniquity not only a safe haven but also a manifest help, and exposing himself and his land to their perversity honoured them as Catholics, and even more than Catholics, calling them Christians for antonomasia ${ }^{16}$.

While those accusations and this list of sanctions are not enough to establish without a doubt that a heresy was developing in Bosnia, Kulin was quick to exculpate himself once he was informed of the irritation of Innocent, probably fearing more the Hungarian intervention that the ecclesiastical sanctions. The pope reported Kulin's conciliatory attempt in a letter sent on 21 November $1202^{17}$, addressed to the archbishop Bernard of Split and John of Casamari, who was in Croatia as well after having returned from a mission to Constantinople ${ }^{18}$, and was probably inspecting the land to ascertain whether the local clergy had complied with the instructions received. According to Innocent, Kulin

excusing himself, answered that he believed that they were not heretics but Catholics, and that he was ready to send to the Apostolic See someone of them as their representative, to expose to us their faith and conduct, so that according to our judgment they would be confirmed in good and diverted from evil, because they want to unwaveringly observe the doctrine of the Apostolic See ${ }^{19}$.

\footnotetext{
${ }^{15}$ Die Register Innocenz' III, 11. Pontifikatsjahr, 1208/1209: Texte und Indices, ed. O. Hageneder, A. Sommerlechner et al., Vienna 2010, p. 35-37, sent on 10 March 1208.

${ }^{16}$ iniquitati eorum non solum tutum latibulum, sed et praesidium contulit manifestum, et, perversitati eorumdem terram suam et se ipsum exponens, ipsos pro catholicis, imo ultra catholicos honoravit, vocans eos antonomastice Christianos: Vetera monumenta slavorum meridionalium..., p. 13.

${ }^{17}$ Die Register Innocenz' III, 5. Pontifikatsjahr, p. 218-219.

${ }^{18}$ The mission was fruitless, not because of John's shortcomings as a legate but due to the irreconcilable positions of Innocent III, John Camaterus and Alexios III. The letters sent by Innocent to the patriarch and the emperor, and delivered by John of Casamari, are recorded in Die Register Innocenz' III, 2. Pontifikatsjahr, p. 382-389 (to Camateros), p. 394-397 (to Alexios). In both letters, John of Casamari is mentioned as 'virum providum et discretum' (p. 389, 397).

${ }^{19}$ Ipse vero semetipsum excusans respondit, quod eos non hereticos sed catholicos esse credebat, paratus quosdam eorum pro omnibus ad sedem apostolicam destinare, ut fidem et conversationem suam nobis exponerent, quatinus nostro iudicio vel confirmarentur in bono vel revocarentur a malo, cum apostolice sedis doctrinam velint inviolabiliter observare: Die Register Innocenz' III, 5. Pontifikatsjahr, p. 218.
} 
The delegation had reached Rome, asking for a legate to be sent in Bosnia to examine the situation, uprooting and planting what he, according to God, will recognize that must be uprooted and planted ${ }^{20}$. Since the purpose of the pope, quoting Ezekiel 33, 11, was not the death of the sinner but his conversion, Innocent decided to send to Bosnia John of Casamari and the bishop of Split so that

\begin{abstract}
if you find among them things reeking of heretical wickedness and contrary to the righteous doctrine, you will bring them back on the right path according to the precept of the faith. And if someone will not comply with your admonishments and commands, proceed against them without appeal, according to the measures we have taken against the heretics ${ }^{21}$.
\end{abstract}

John of Casamari, just as he did in Dioclea, carried out his mission with admirable zeal and energy. On 10 June 1203 he wrote to Innocent regarding "illorum quondam Patarinorum in Bosna", assuring him that the matter had been addressed successfully ${ }^{22}$. He informed the pope that the whole Bosnian territory was under the jurisdiction of only one bishop, who had recently died: it would be wise to send someone from Rome, and to divide the region in four or five bishopric. But most importantly, he attached a document signed by the Bosnian clergy and by Kulin, in which they declared themselves ready to accept the deliberations of the pope regarding the ecclesiastical organization of the lands of Bosnia ${ }^{23}$. Although, as it will presently become evident, the local clergy did indeed exhibit some peculiar customs, in the declaration there are no mentions of heretical practices that could be connected to the patarene heresy, if not very vaguely. After a formal recognition of the authority of the Roman Church, the signatories swore:

in all churches we will have altars and crosses; we will certainly read the books of the old and of the new testament, as the Roman Church does. In every place we will have ministers, who at least on Sundays and on high days will celebrate mass according to the ecclesiastic orders, hear confessions and assign penitences. We will have graveyards near the churches, where we will bury our brothers and the wayfarers, should they die there. At least seven times a year we will receive the body of the Lord from the hands of a minister [...] We will observe the fasting prescribed by the Church, and we will keep the traditions providentially established by our predecessors. Without doubt, the women who belong to our religion will be separated from

\footnotetext{
${ }^{20}$ evellens et plantans, que secundum Deum evellenda cognoverit et plantanda: Die Register Innocenz' III, 5. Pontifikatsjahr, p. 219.

${ }^{21}$ Si qua vero inveneritis inter eos, que sapiant hereticam pravitatem et sane adversentur doctrine, ad viam veritatis secundum fidei regulam reducatis. Quodsi forsan monitis et mandatis vestris noluerint acquiescere, vos in eos appellatione remota secundum constitutionem, quam edidimus, adversus hereticos procedatis: Die Register Innocenz' III, 5. Pontifikatsjahr, l. cit.

${ }^{22}$ Die Register Innocenz' III, 6. Pontifikatsjahr, 1203/1204: Texte und Indices, ed. O. Hageneder et al., Vienna 1995, p. 229-231. The quotation is from p. 230. On his activity in Bosnia see I. Majnarić, Papinski kapelan Ivan od Casamarija i bilinopoljska abjuracija 1203. Papinski legat koji to u Bosni nije bio?, RZav 50, 2008, p. 1-13.

${ }^{23}$ Die Register Innocenz' III, 6. Pontifikatsjahr, p. 231-233.
} 
the men in the dormitories and in the refectories, and no brother will be allowed to meet one of them alone, so that a sinister suspicion may arise. Furthermore, we will not accept a married man or woman, if they will not both convert and promise continence by mutual consent. We will celebrate the saints' festivals as ordained by the holy fathers, and we will not welcome to live among us any notorious manichaean or any other heretic. And, just as we are distinguished from the laity by our life and behaviour, in the same way we will be separated by the manner of our clothes; because the clothes will be closed, uncoloured, and long to the heels. Moreover we will not call ourselves Christians, as we have done until now, but brothers... ${ }^{24}$

Imre, in a letter sent to Innocent probably in September 1203, added more details ${ }^{25}$. In the presence of the Hungarian king and of the archbishop of Kalocsa, Kulin had solemnly sworn not to receive any heretic in his lands, under a penalty of one thousand silver marks. One half of the sum would be given to Imre, the rest to Rome.

Judging from the errors that the Bosnian clergy swore to correct, its situation before the intervention of John of Casamari (who, as noted before, qualified them as 'Paterenes') certainly appears unorthodox, and bordering heresy in some points. Yet, John did not point out any doctrinal fallacy in the Bosnian Church: evidently, he believed that the fundamental tenets of the Christian religion were well grounded, and did not need any major intervention from Rome. Before returning to Italy, he was asked to fulfil a last mission. While he was busy with the affairs of Bosnia, Innocent had entered into negotiations with the Bulgarian tsar Kalojan, who assumed the throne in 1197, and in the spring of $1203 \mathrm{John}$ of Casamari was sent in the Bulgarian capital, Tărnovo ${ }^{26}$.

\footnotetext{
${ }^{24}$ In omnibus autem ecclesiis habebimus altaria et cruces; libros vero tam novi quam veteris testamenti, sicut facit ecclesia Romana, legemus. Per singula loca nostra habebimus sacerdotes, qui Dominicis et festivis diebus ad minus missas secundum ordinem ecclesiasticum debeant celebrare, confessiones audire et penitentias tribuere. Cimiteria habebimus iuxta oratoria, in quibus fratres sepeliantur et adventates, si casu ibi obierint. Septies in anno ad minus corpus Domini de manu sacerdotis accipiemus [...] Ieiunia constituta ab ecclesia observabimus et ea, que maiores nostri provide preceperunt, custodiemus. Femine vero, que de nostra erunt religione, a viris separate erunt tam in dormitoriis quam in refectoriis, et nullus fratrum solus cum sola confabulabitur, unde possit sinistra suspicio suboriri. Neque decetero recipiemus aliquem vel aliquam coniugatam, nisi mutuo consensu continentia promissa ambo pariter convertantur. Festivitates autem sanctorum a sanctis patribus ordinatas celebrabimus et nullum deinceps ex certa scientia Manicheum vel alium hereticum ad habitandum nobiscum recipiemus. Et sicut separamur ab aliis secolaribus vita et conversatione, ita etiam habitu secernamur vestimentorum; que vestimenta erunt clausa non colorata, usque ad talos mensurata. Nos autem decetero non Christianos, sicut hactenus, sed fratres nos nominabimus...: Die Register Innocenz' III, 6. Pontifikatsjahr, p. 232.

${ }^{25}$ Die Register Innocenz' III, 6. Pontifikatsjahr, p. 361-362.

${ }^{26}$ The bibliography on the Second Bulgarian kingdom (or empire, as it is sometimes called) from its establishment to the rule of tsar Kalojan (1197-1207) is very extensive. Among the most comprehensive surveys, see especially A. Madgearu, The Asanids. The Political and Military History of the Second Bulgarian Empire (1185-1280), Leiden 2017, p. 29-174; И. Божилов, Фамилията на Асеневци (1186-1460). Генеалогия и просопография, София 1994, р. 27-68. On the correspondence between Innocent III, Kalojan and the archbishop of Tărnovo Vassili, see И. Дуйчев, Преписката
} 
The first contact with Bulgaria dated back to the period between the end of 1199 and February 1200, by initiative of the same Innocent who, as said before, was trying to extend as much as possible the network of his allies to isolate Constantinople and force the reluctant empire to participate in the crusade. Innocent sent in Bulgaria Dominic, "archipresbyterum Grecorum" of Brindisi, in order to establish relations with Kalojan and ascertain his willingness to cooperate with Rome $^{27}$. At least in the beginning, however, Kalojan's disposition towards Rome was not benevolent. Dominc was detained for a long time, until, in the end of 1202, the Bulgarian tsar finally decided to answer in a conciliatory tone ${ }^{28}$. An agreement with Rome would indeed benefit Bulgaria. While the country was part of the Orthodox community, Kalojan needed to obtain from a recognized authority the legitimisation of his royal rank, in order to be considered by his generally hostile neighbours as the tsar of an independent polity, and not a usurper who had seceded from the Byzantine empire and whose lands did not actually belong to him. The royal status of his predecessors, his brothers Peter and Asen, had not been formally recognized by the empire or by Hungary, and both polities were laying claims to the Bulgarian territory, or to parts of it. The ecclesiastical situation of Bulgaria was also very complicated. After the secession in 1185, the new kingdom reinstated the autonomy of the Bulgarian Church from the patriarchate of Constantinople: but the archbishop of Tărnovo Vassili, who had crowned Kalojan and his predecessors, had been elevated to his rank in an uncanonical way, and his authority was not recognized by the Byzantine clergy ${ }^{29}$. The intervention of Innocent III could solve this issue as well, and the kingdom of Bulgaria would be able to recover both his political and ecclesiastical autonomy "as it had been in the past" ${ }^{30}$, to quote the words of Niketas Choniates.

So, after the initial misunderstandings the relations between Rome and Tărnovo became friendly and collaborative, favoured by the political advantages that both parties could gain. Apart from some very formal professions of obedience, Kalojan made it clear that his desire was to receive a royal crown and the canonical sanction for the autocephaly of the Bulgarian $\mathrm{Church}^{31}$, and some diplomatic

на папа Инокентий ІІІ с българите. Увод, текст и коментар, ГСУ.ИФФ 38, 3, 1942, р. 71-116; F. Dall'Aglio, Innocenzo III e i Balcani. Fede e politica nei 'Regesta' pontifici, Napoli 2003.

${ }^{27}$ Die Register Innocenz' III, 2. Pontifikatsjahr, p. 486.

${ }^{28}$ Die Register Innocenz' III, 5. Pontifikatsjahr, p. 224-226.

${ }^{29}$ Demetrii Chomateni Ponemata Diaphora, ed. G. PrinzIng, Berlin 2002 [= CFHB, 38], p. 50, 423-424; Б. Николова, Устроиство и управление на българската православна цьрква, IX-XIV век, София 1997, p. 196-198; I. TARNANIDIs, Byzantine-Bulgarian Ecclesiastical Relations during the Reigns of Ioannis Vatatzis and Ivan Asen II, up to the Year 1235, Cyr 3, 1975, p. 28 -52 (here p. 28, $41,45-47)$.


[= CFHB.SBe, 11], p. 371.

${ }^{31}$ Inprimis petimus ab ecclesia Romana, matre nostra, coronam et honorem tamquam dilectus filius, secundum quod imperatores nostri veteres habuerunt: Die Register Innocenz' III, 5. Pontifikatsjahr, 
assistance against Hungary and against his new and troublesome neighbour, the Latin empire of Constantinople ${ }^{32}$. Innocent, for the motivations we have already examined, was glad to oblige him. Again, as in the cases of Serbia and Bosnia, the complete lack of any discussion about Christian doctrine is striking, since from the point of view of the pontiff Bulgaria should have been considered at least heterodox, and before accepting its subordination to Rome many measures should have been taken to ensure a strict adherence to the principles of Roman Catholicism. Still, the only issue discussed at length by Innocent and Vassili was the anointment of the clergy and of the sovereign, a matter held in very high regard by the pope and argued with an impressive display of patristic erudition ${ }^{33}$. Also, the pope did not accept to elevate the rank of Vassili to that of patriarch: Vassili had to content himself with the title of primate of the Church of Bulgaria and Vlachia since, according to Innocent's explanation, primate and patriarch mean almost the same thing ${ }^{34}$. Vassili made no objections, as did the rest of the Bulgarian clergy who, generally speaking, accepted the union with Rome without complaining, although the lack of Bulgarian sources leaves this point open to debates.

If the two points quoted above were the only theological matters discussed between Innocent and Vassili, one might well wonder how strict the obedience of the Bulgarian Church to the rules set by Rome had been, and if it is possible to consider it orthodox, in the sense that the Roman pontiff would have attached to the word. Moreover, it is questionable whether Innocent was really interested in any discourse of orthodoxy and heterodoxy, and possibly of heresy as well, when political concerns, rather than religious, were the main focus of his considerations. Among many other things, Innocent III is remembered, and with good reasons, as having been extremely stern against non-conformity within the Church, which he saw as necessarily united under the authority of the pope. Yet,

\footnotetext{
p. 225 (sent at the end of 1202); Et rogo per orationes beati apostoli Petri et per sanctas orationes tuas, ut tu mittas cardinales [...] ut me coronent in imperatorem et in terra mea faciant patriarcham: Die Register Innocenz' III, 6. Pontifikatsjahr, p. 235 (sent in June 1203).

${ }^{32}$ Et de confinio Hungarie, Bulgarie et Blachie relinquo iudicio sanctitatis tue, ut dirigas negocium istud recte et iuste [...] Sciat autem sanctitas tua, quoniam V episcopatus Bulgarie pertinent ad imperium meum, quos invasit et detinet rex Hungarie: Die Register Innocenz' III, 7. Pontifikatsjahr, p. 20 (sent after 8 September 1203); Scribo atque vobis et de Vngaro, quoniam imperium meum non habet aliquam societatem regionum vel aliquam rem cum eo necque ei nocet, immo ipse parvipendit et nocet regionibus imperii mei [...] Et scribat ei sanctitas vestra, quatinus distet a regno meo [...] De Latinis quoque, qui Constantinopolim introierunt, scribo sanctitati vestre, ut eis scribatis, quatinus distent ab imperio meo et sic imperium meum nullum malum eis facit neque ipsi nobis parvipendant: Die Register Innocenz' III, 7. Pontifikatsjahr, p. 410-411 (sent between 8 and 15 November 1204).

${ }^{33}$ Die Register Innocenz' III, 7. Pontifikatsjahr, p. 9-13.

${ }^{34}$ Fraternitatem tuam scire volentes, quod apud nos hec duo nomina, primas et patriarcha, pene penitus idem sonant, cum primates et patriarche teneant unam formam, licet eorum nomina sint diversa: Die Register Innocenz' III, 7. Pontifikatsjahr, p. 7.
} 
in South-eastern Europe his supposed intransigence does not seem to have been exercised with the same energy displayed in other countries. On the contrary, his actions and deliberations appear extremely cautious, if not downright hesitant, beyond the obvious statements of principle and the binding legal norms which regulated the life of the Church, and that had to be enforced without reservations. This behaviour has some logical explanations. South-eastern Europe was an area in which the presence of the Roman Church was not firmly rooted, and were the number of its enemies far outnumbered that of his allies or subordinates. The local kingdoms had to be convinced to join the cause of Innocent, and some concessions and a modicum of leniency were to be expected in such an important strategic area, especially when a crusade was on its way and the Byzantine empire seemed unable to mount up a resolute opposition to Innocent's offensive. The prospect of finally uniting the Eastern and the Western Church surely persuaded the pope to allow a modicum of heterodoxy in his new subjects, and avoid the danger of alienating them with an excessive severity. A significant proof of this attitude came shortly after the battle of Adrianople of 14 April 1205, where the Bulgarian army inflicted a crushing defeat upon the newly established Latin empire of Constantinople and captured its emperor, Baldwin of Flandres and Hainaut. Innocent, informed of the events through a letter written to him on 5 June 1205 by Henry, Baldwin's brother and regent of the empire ${ }^{35}$, and so worried that the enmity between the Latins and Bulgaria could compromise the future expeditions to the Holy Land that he decided to organize a crusade to aid the empire ${ }^{36}$, tried to reconcile the enemies and wrote to Kalojan and Henry: but he addressed the two sovereigns in a very different way. The letter sent to Henry is brief and dry, a dispatch more than a letter:

we order your nobility [...] that, since you are diligently striving for the liberation of your brother, you establish a true and firm peace with our dearest son in Christ Kalojan, the illustrious king of the Bulgarians and the Vlachs, so that a true and faithful friendship will pursue between the Bulgarians and the Latins. We write in brief, because the matter must be addressed with deeds more than words. ${ }^{37}$

${ }^{35}$ Die Register Innocenz' III, 8. Pontifikatsjahr, 1205/1206: Texte und Indices, ed. O. Hageneder, A. Sommerlechner et al., Vienna 2001, p. 239-243.

${ }^{36}$ Die Register Innocenz' III, 8. Pontifikatsjahr, p. 238-239, sent on 16 August 1205 to Universis Christi fidelibus ad succursum Terre sancte volentibus Costantinopolim proficisci. Very few soldiers did actually reach Constantinople in the following years: for the organization of this ineffective crusade see N. Chrissis, Crusading in Frankish Greece. A Study of Byzantine-Western Relations and Attitudes, 1204-1282, Turnhout 2012, p. 24-29.

${ }^{37}$ Nobilitati tue [...] mandamus, quatinus ad liberationem fratris tui diligenter intendens veram et firmam pacem stabilias cum karissimo in Christo filio nostro Kaloioh(ann)e, rege Bulgarorum et Blachorum illustri, ut inter Bulgaros et latinos fidelis et stabilis amicitia decetero perseveret. Breviter scribimus, quia opus est magis opere quam sermone: Die Register Innocenz' III, 8. Pontifikatsjahr, p. 243-244 (sent around 16 August 1205). 
The tone of the letter addressed to Kalojan is much more conciliatory, although Innocent tried to scare the Bulgarian sovereign announcing that the empire would soon receive reinforcements from the West and from Hungary:

By virtue of that special benevolence, with which we glorified you among all the Christian princes, we love you to the point that we actively aspire to your advantage and honour [...] Therefore we suggest and counsel in good faith to your serenity that, since you are said to be keeping prisoner Baldwin, the emperor of Constantinople, you think of your own good, and through his liberation you establish a true and firm peace with the Latins. ${ }^{38}$

Probably, however, Baldwin was already dead before the letters reached their recipients, and possibly even before Innocent was informed of the battle of Adrianopolis. Henry tried to present Kalojan and his successor Boril as enemies of the Church and of the Christian faith altogether, asking for reinforcements and considering the military operations aimed at defending the empire as the equivalent of a crusade against the enemies of Christianity. Already in the letter he sent to Innocent in June 1205, Henry had insinuated that Kalojan's disposition towards the Christian faith was ambiguous, because he was organising an alliance with the Turks and with other enemies of the cross of Christ ${ }^{39}$. In the following year, in a letter sent in September 1206 to his brother Godfrey ${ }^{40}$, he repeated the concept in a much more explicit way, calling Kalojan sancte crucis inimico (enemy of the holy cross), crucis inimicus (enemy of the cross), and curiae et sancte romane ecclesie inimicus (enemy of the curia and of the holy Roman church) ${ }^{41}$. Apparently, Innocent was not convinced. In the last letter he wrote to the Bulgarian tsar on 24 May 1207, he invited him again to make peace with the empire and, while the general tone is indeed colder, he continued to express benevolence towards him, hoping for a rapprochement between Bulgaria and the Latins ${ }^{42}$. Finally, the Bulgarian clergy was dutifully invited to the Fourth Lateran Council, a certain proof of the fact that the country was still regarded as Christian and obedient to Rome.

\footnotetext{
${ }^{38}$ Ex illa gratia speciali, qua te glorificavimus inter omnes principes christianos, usque adeo te diligimus, ut ad tuum comodum et honorem efficaciter aspiremus [...] Quocirca serenitati tue suggerimus et consulimus recta fide, quatinus, cum Balduinum, Constantinopolitanum imperatorem, dicaris tenere captivum, ita tibi provideas, ut per liberationem ipsius veram et firmam pacem facias cum Latinis: Die Register Innocenz' III, 8. Pontifikatsjahr, p. 237 (sent around 16 August 1205).

${ }^{39}$ Confederationem ipsius cum Turcis et ceteris crucis Christi inimicis: Die Register Innocenz' III, 8. Pontifikatsjahr, p. 242.

${ }^{40}$ The letter to Gottfried is edited in G. Tafel, G. Thomas, Urkunden zur älteren Handels- und Staatsgeschichte der Republik Venedig, vol. II, Amsterdam 1964 [repr.], p. 38-42. It was sent in copy to Innocent as well.

${ }^{41}$ G. Tafel, G. Thomas, Urkunden..., vol. II, p. 38, 39, 42. "Curiae" is an emendation suggested by G. Tafel and G. Thomas, but the text may well be "crucis," repeating the formula already used by Henry in his invective against Kalojan.

${ }^{42}$ Die Register Innocenz' III, 10. Pontifikatsjahr, 1207/1208: Texte und Indices, ed. R. Murauer, A. Sommerlechner et al., Vienna 2007, p. 112-113.
} 
This very short survey of Innocent III's politics in South-eastern Europe cannot lay claim to exhaustiveness. Its purpose, and hopefully its merit, was to remind the reader, but especially the writer, that while it is indeed tempting to consider declarations and actions as the same thing, it is necessary to vet them carefully, to avoid mistaking simple words, however heartfelt and sincere, for the truth of the matter. Innocent's legislation against the heretics was indeed severe, and the problem concerned him very much. Yet, as the skilled politician he was, when he had to choose between reasons of State and stubborn obedience to his principles, he was more than willing to negotiate.

\section{Bibliography}

\section{Primary Sources}

Acta Innocentii PP. III (1198-1216), ed. T. HaluščYNSKYJ, Vatican City 1944 [= Pontificia commissio ad redigendum codicem iuris canonici orientalis. Fontes, 3.2].

Demetrii Chomateni Ponemata Diaphora, ed. G. PrinzING, Berlin 2002 [= Corpus fontium historiae byzantinae, 38].

DujČEv I., Prepiskata na papa Inokentij III s bălgarite. Uvod, tekst i komentar, “Годишник на Софийския Университет. Историко-Филологически факултет” / "Godišnik na Sofijskija Universitet. Istoriko-Filologičeski fakultet" 38, 3, 1942, p. 71-116.

Nicetae Choniatae Historia, ed. J.-L. van Dieten, Berlin-New York 1975 [= Corpus fontium historiae byzantinae. Series Berolinensis, 11].

Regesta pontificum romanorum, vol. I, ed. A. Роттнаsт, Graz 1957.

Die Register Innocenz' III, 1. Pontifikatsjahr, 1198/1199: Texte, ed. O. Hageneder, A. Haidachert, Graz-Köln 1964.

Die Register Innocenz' III, 2. Pontifikatsjahr, 1199/1200: Texte, ed. O. HAGENEDER et al., Rome-Vienna 1979.

Die Register Innocenz' III, 5. Pontifikatsjahr, 1202/1203: Texte, ed. O. HAGENEDER et al., Vienna 1993.

Die Register Innocenz' III, 6. Pontifikatsjahr, 1203/1204: Texte und Indices, ed. O. HaGeneder et al., Vienna 1995.

Die Register Innocenz' III, 7. Pontifikatsjahr, 1204/1205: Texte und Indices, ed. O. Hageneder et al., Vienna 1997.

Die Register Innocenz' III, 8. Pontifikatsjahr, 1205/1206: Texte und Indices, ed. O. Hageneder, A. SOMMERLeCHNER et al., Vienna 2001.

Die Register Innocenz' III, 10. Pontifikatsjahr, 1207/1208: Texte und Indices, ed. R. Murauer, A. SomMERLECHNER et al., Vienna 2007.

Die Register Innocenz' III, 11. Pontifikatsjahr, 1208/1209: Texte und Indices, ed. O. Hageneder, A. SOMMERLECHNER et al., Vienna 2010.

Vetera monumenta slavorum meridionalium historiam illustrantia, vol. I, ed. A. TheIner, Rome 1836. 


\section{Secondary Literature}

Barabás G., Heretics, Pirates, and Legates. The Bosnian Heresy, the Hungarian Kingdom, and the Popes in the Early $13^{\text {th }}$ Century, "Specimina Nova, Pars Prima. Sectio Mediaevalis" 9, 2017, p. 35-58.

Bird J., Innocent III, Peter the Chanter's Circle, and the Crusade Indulgence: Theory, Implementation, and Aftermath, [in:] Innocenzo III. Urbs et Orbis. Atti del Congresso Internazionale (Roma, 9-15 settembre 1998), vol. I, ed. A. SOMMERLECHNER, Rome 2003, p. 503-524.

Božılov I., Familijata na Asenevci (1186-1460). Genealogija i prosopografija, Sofija 1994.

Chrissis N., Crusading in Frankish Greece. A Study of Byzantine-Western Relations and Attitudes, 1204-1282, Turnhout 2012.

Dall'Aglio F., Innocenzo III e i Balcani. Fede e politica nei 'Regesta' pontifici, Napoli 2003.

Dautović D., Crkva Bosanska: moderni historiografski tokovi, rasprave i kontroverze (2005-2015), "Historijska traganja" 15, 2015, p. 127-160.

Elze R., Die päpstliche Kapelle im 12. und 13. Jahrhundert, "Zeitschrift der Savigny-Stiftung für Rechtsgeschichte. Kanonistische Abteilung” 36, 1, 1950, p. 145-204.

Fedalto G., La Chiesa latina in Oriente, vol. I, ${ }^{2}$ Verona 1981.

Fenomen "krstjani" u srednjovjekovnoj Bosni i Humu, ed. F. ŠAnjek, Sarajevo-Zagreb 2005.

Filipović E., Bosansko kraljevstvo. Historija srednjovjekovne bosanske države, Sarajevo 2016.

Fine J.V.A. JR., The Bosnian Church. A New Interpretation, New York 1975.

Giovanni da Casamari in Dalmazia e Bosnia, ed. N. Veselic, Rome 2019.

HAgeneder O., Studien zur Dekretale "Vergentis" (X. V, 7, 10): Ein Beitrag zur Häretikergesetzgebung Innocenz' III, "Zeitschrift der Savigny-Stiftung für Rechtsgeschichte. Kanonistische Abteilung” 49, 1963, p. 138-173.

Hamilton J., Hamilton B., Christian Dualist Heresies in the Byzantine World c. 650-c. 1450, Manchester 1998.

Innocenzo III. Urbs et Orbis. Atti del Congresso Internazionale (Roma, 9-15 settembre 1998), vol. II, ed. A. SOMMERLECHNER, Rome 2003.

Kamp N., Kirche und Monarchie im staufischen Königreich Sizilien. Prosopographische Grundlegung: Bistümer und Bischöfe des Königreichs 1194-1266, vol. I, Munich 1973.

Kay R., The Albigensian Twentieth of 1221-3: an Early Chapter in the History of Papal Taxation, "Journal of Medieval History" 6, 1980, p. 307-315.

Madgearu A., The Asanids. The Political and Military History of the Second Bulgarian Empire (1185-1280), Leiden 2017.

Majnarić I., Papinski kapelan Ivan od Casamarija i bilinopoljska abjuracija 1203. Papinski legat koji to u Bosni nije bio?, "Radovi Zavoda za povijesne znanosti HAZU u Zadru" 50, 2008, p. 1-13.

Maleczek W., Papst und Kardinalkolleg von 1191 bis 1216, Vienna 1984.

Moore J.C., Pope Innocent III (1160/61-1216). To Root up and to Plant, Leiden 2003.

Nikolova B., Ustroistvo i upravlenie na bălgarskata pravoslavna cărkva, IX-XIV vek, Sofija 1997.

Papadakis A., TAlвot A.M., John X Camaterus Confronts Innocent III: an Unpublished Correspondence, "Byzantinoslavica. Revue internationale des études byzantines" 33, 1972, p. 26-41.

Powell J.M., Anatomy of a Crusade, 1213-1221, Philadelphia 1986. 
Powell J.M., Innocent III and Alexios III: a Crusade Plan that Failed, [in:] The Experience of Crusading, vol. I, ed. M. BulL, N. Housley, Cambridge 2003, p. 96-102.

SPITERIS J., La critica bizantina del primato romano nel secolo XII, Rome 1979.

Šтıмac Z., Die bosnische Kirche. Versuch eines religionswissenschaftlichen Zugangs, Frankfurt 2004.

Tafel G., Thomas G., Urkunden zur älteren Handels- und Staatsgeschichte der Republik Venedig, vol. II, Amsterdam 1964 [repr.].

TARnanidis I., Byzantine-Bulgarian Ecclesiastical Relations during the Reigns of Ioannis Vatatzis and Ivan Asen II, up to the Year 1235, "Cyrillomethodianum" 3, 1975, p. 28-52.

\begin{abstract}
In the beginning of the pontificate of Innocent III (1198-1216) the necessity of creating a large coalition for a better organization of the Fourth Crusade convinced the pope to establish diplomatic relations with Bulgaria and Serbia, and to support Hungarian expansion in Bosnia. His aim was to surround Constantinople with a ring of states loyal to the Roman Church, thus forcing the empire to participate in the crusade. In order to achieve this result, Innocent was more than willing to put aside his concerns for strict religious orthodoxy and allow the existence, to a certain extent, of non-conforming practices and beliefs in the lands of South-eastern Europe. While this plan was successful at first, and both Bulgaria and Serbia recognized pontifical authority in exchange for political legitimization, the establishment of the so-called Latin empire of Constantinople in 1204 changed the picture. Its relations with Bulgaria were extremely conflicted, and the threat posed by Bulgaria to the very existence of the empire forced again Innocent III to a politics of compromise. The survival of the Latin empire was of the greatest importance, since Innocent hoped to use it as a launching point for future crusades: yet, he tried until possible to maintain a conciliatory politics towards Bulgaria as well.
\end{abstract}

Keywords: Church studies, crusade studies, medieval Bulgaria, Latin Empire of Constantinople, medieval Bosnia, medieval Serbia, medieval heresies, Innocent III

Francesco Dall'Aglio

Bulgarian Academy of Sciences

Institute for Historical Studies

B. Šipčeski Prohod 52, blok 17

1113 Sofia, Bulgaria

fra.dallaglio@gmail.com 